PUBLISHER CORRECTION

\title{
Publisher Correction: Rolf Neth (October 6, 1926-March 17, 2020)
}

Rüdiger Hehlmann, Robert Gallo, Dieter Hoelzer, Karl Welte, Robert Peter Gale and Axel Zander

(C) The Author(s) 2021

Leukemia (2021) 35:3638; https://doi.org/10.1038/s41375-021-01356-5

Correction to: Leukemia https://doi.org/10.1038/s41375-020-0829-

6, published online 08 April 2020

The article Rolf Neth (October 6, 1926-March 17, 2020), written by Rüdiger Hehlmann, Robert Gallo, Dieter Hoelzer, Karl Welte, Robert Peter Gale \& Axel Zander, was originally published electronically on the publisher's internet portal on 08 April 2020 without open access. With the author(s)' decision to opt for Open Choice the copyright of the article changed on 26. May 2021 to $\odot$ The Author (s) 2021, the article is forthwith distributed under a Creative Commons Attribution

\section{FUNDING}

Open Access funding enabled and organized by Projekt DEAL. (c) Open Access This article is licensed under a Creative Commons Attribution 4.0 International License, which permits use, sharing, adaptation, distribution and reproduction in any medium or format, as long as you give appropriate credit to the original author(s) and the source, provide a link to the Creative Commons license, and indicate if changes were made. The images or other third party material in this article are included in the article's Creative Commons license, unless indicated otherwise in a credit line to the material. If material is not included in the article's Creative Commons license and your intended use is not permitted by statutory regulation or exceeds the permitted use, you will need to obtain permission directly from the copyright holder. To view a copy of this license, visit http://creativecommons. org/licenses/by/4.0/.

(c) The Author(s) 2021 